\title{
Electrochemical Advanced Oxidation Processes (EAOPs) for Disinfecting Water-Fresh Perspectives
}

\author{
Djamel Ghernaout ${ }^{1,2 *}$, Noureddine Elboughdiri1,3, Saad Ghareba1,4, Alsamani Salih ${ }^{1,5}$ \\ ${ }^{1}$ Chemical Engineering Department, College of Engineering, University of Ha'il, Ha'il, Saudi Arabia \\ ${ }^{2}$ Chemical Engineering Department, Faculty of Engineering, University of Blida, Blida, Algeria \\ ${ }^{3}$ Département de Génie Chimique de Procédés, Laboratoire Modélisation, Analyse, et Commande des systèmes, Ecole Nationale \\ d'Ingénieurs de Gabès (ENIG), Gabès, Tunisia \\ ${ }^{4}$ Department of Chemical and Petroleum Engineering, El Mergib University, Alkhums, Libya \\ ${ }^{5}$ Department of Chemical Engineering, Faculty of Engineering, Al Neelain University, Khartoum, Sudan \\ Email: ^djamel_andalus@hotmail.com
}

How to cite this paper: Ghernaout, D., Elboughdiri, N., Ghareba, S. and Salih, A. (2020) Electrochemical Advanced Oxidation Processes (EAOPs) for Disinfecting WaterFresh Perspectives. Open Access Library Journal, 7: e6257.

https://doi.org/10.4236/oalib.1106257

Received: March 23, 2020

Accepted: April 6, 2020

Published: April 9, 2020

Copyright $\odot 2020$ by author(s) and Open Access Library Inc.

This work is licensed under the Creative Commons Attribution International License (CC BY 4.0).

http://creativecommons.org/licenses/by/4.0/

(c) (i) Open Access

\begin{abstract}
During recent decades, study endeavors have been performed at elaborating more efficient techniques for handling waters carrying pathogens. Among such methods, the famous electrochemical advanced oxidation processes (EAOPs) have induced augmenting attention. Such methods are founded on electrochemically producing powerful oxidants like hydroxyl radicals $\left({ }^{\bullet} \mathrm{OH}\right)$. This work portrays a global view on killing different microorganisms by some usual EAOPs. Electrochemically-driven techniques are earning importance thanks to encouraging findings noted in the literature. A shortage of comprehension in the pathways of electrode scaling and fouling has happened partially, because the most investigation is realized in batch reactors rather than continuous flow reactors where solutes and pathogens that noxiously influence setup efficiency pass by electrode surfaces. The coming study has to deal with the treatment of more realistic water matrices (i.e., composition and concentration). This will help to identify fit-for-purpose and niche opportunities for electrochemically-driven technologies.
\end{abstract}

\section{Subject Areas}

Chemical Engineering \& Technology, Electric Engineering

\section{Keywords}

Electrochemical Advanced Oxidation Processes (EAOPs), Hydroxyl Radical, Fenton Reaction, Reactive Oxygen Species (ROSs), Reactive Chlorine Species (RCSs), Boron-Doped Diamond (BDD) 


\section{Introduction}

During the last three decades, electrochemical advanced oxidation processes (EAOPs) have been largely expanded as substitutional treatments for eliminating poisonous species, like persistent organic pollutants from water, wastewater, soil-washing wastes, landfill leachate and effluents of numerous industrial factories, comprising the treatment of reverse osmosis concentrates [1] [2] [3] [4]. Founded on generating electrochemically the hydroxyl radical, such technologies are distinctive, since they have several merits over other advanced oxidation processes (AOPs) and even, in some circumstances, over many commercial wastewater treatment techniques, such as the biological treatments or the membrane filtration processes [5] [6] [7]. Consequently, they show an extremely elevated energy performance, high versatility, great amenability, and outstanding environmental compatibility; further, they are greatly performant in eliminating all types of organic matters [8]. Thanks to their high versatility, a big set of EAOPs has been tested through the previous decades worldwide for decomposing electrochemically numerous categories of recalcitrant organic contaminants and their basic concepts and usages are discussed in many publications [1] [9] [10].

EAOPs are known as hydroxyl radical $\left({ }^{\bullet} \mathrm{OH}\right)$-mediated electrochemical treatments, where contaminants are broken by electrochemically produced reactive oxygen species (ROSs), mostly ${ }^{\circ} \mathrm{OH}$ and oxidants generated from such strong radical [1] [11] [12] [13]. Indeed, ${ }^{\bullet} \mathrm{OH}$ remains an extremely vigorous oxidizing factor that reacts non-selectively with organic compounds, leading to their oxidation up to reaching a so elevated mineralization level or, in most situations, their total burning to $\mathrm{CO}_{2}$, water and inorganic ions [14]. In a general manner, EAOPs could be classified into two classes: 1) electrooxidation/anodic oxidation and 2) Fenton's reaction founded electrochemical processes (electro-Fenton, solar [15] [16] and UV photoelectro-Fenton and heterogeneous electro/photoelectro-Fenton processes) [1] [10].

In electrooxidation (EO), organic chemicals are oxidized in the anode via formed ROSs electrochemically (Equations (1) and (2)), either physisorbed or chemisorbed ${ }^{\bullet} \mathrm{OH}$ following the electrode material/electrocatalyst employed [1]. Therefore, many anode materials interact powerfully with the produced radical and raise its oxidation to chemisorbed oxygen or superoxide $(\mathrm{M}=\mathrm{O})$ [1]. Such materials, familiar as "active anodes", have low oxygen evolution overpotential (like $\mathrm{Pt}, \mathrm{Ru}$, and $\mathrm{Ir}$ founded mixed metal oxides and graphite-carbon electrodes) and could only attain a soft decomposition of organic contaminants (electrochemical conversion) with so restricted mineralization level [1]. Other anodes (known as "nonactive") possess higher oxygen evolution overpotential and interact weakly with the formed radicals (like doped $\mathrm{PbO}_{2}, \mathrm{SnO}_{2}$, boron-doped diamond (BDD), sub-stoichiometric titanium oxide $\left.\left(\operatorname{Ti}_{\mathrm{x}} \mathrm{O}_{2 \mathrm{x}-\mathrm{I}}\right)\right)$, therefore letting them to freely react with organic chemicals up to their final mineralization (electrochemical combustion) [1]. In anodic oxidation methods, several other oxidants are formed on the anode surface, like ozone, hydrogen peroxide, and 
peroxosalts. They interact with organic compounds in the bulk and they are in charge of the elevated performance of such technologies.

$$
\begin{gathered}
\mathrm{M}_{(\mathrm{s})}+\mathrm{H}_{2} \mathrm{O} \rightarrow \mathrm{M}\left({ }^{\bullet} \mathrm{OH}\right)+\mathrm{OH}^{-}+\mathrm{e}^{-} \\
\mathrm{M}\left({ }^{\bullet} \mathrm{OH}\right) \rightarrow \mathrm{M}=\mathrm{O}+\mathrm{H}^{+}+\mathrm{e}^{-}
\end{gathered}
$$

In such a direction, it is crucial to clarify that when remedying solutions carrying elevated level of $\mathrm{Cl}^{-}$ions (such as reverse osmosis brines [3]), reactive chlorine species (RCSs) $\left(\mathrm{Cl}_{2}, \mathrm{HClO}\right.$, and/or $\mathrm{ClO}^{-}$which are prevalent at $\mathrm{pH}<$ 3.0, $3.0-6.5$ and $>8.0$, respectively) (Figure 1) are formed in the bulk solution through reactions (Equations (3-5)) along with ROSs [1] [17]. The RCSs are somewhat powerful oxidants that could efficaciously decompose any category of organic contaminants. Nevertheless, such technique constantly conducts to the generation of poisonous by-products, particularly haloacetic acids and trihalomethanes and diverse recalcitrant organochlorinated intermediates which are hard to mineralize [1] [18] [19] [20].

$$
\begin{aligned}
2 \mathrm{Cl}^{-} & \rightarrow \mathrm{Cl}_{2}+2 \mathrm{e}^{-} \\
\mathrm{Cl}_{2}+\mathrm{H}_{2} \mathrm{O} & \rightarrow \mathrm{HClO}+\mathrm{Cl}^{-}+\mathrm{H}^{+} \\
\mathrm{HClO} & \leftrightarrow \mathrm{ClO}^{-}+\mathrm{H}^{+}
\end{aligned}
$$

Fenton's founded electrochemical techniques produce homogeneous ${ }^{\bullet} \mathrm{OH}$ indirectly from the reaction among $\mathrm{H}_{2} \mathrm{O}_{2}$ and catalytic $\mathrm{Fe}^{2+}$ (Fenton's reagents, Equation (6)), completely or relatively formed electrochemically in situ throughout the electrolysis at acidic $\mathrm{pH}$ degrees ( $\mathrm{pH} 2.8$ - 3.5) [1] [10]. Such a technique is more performant than $\mathrm{EO}$ at similar working parameters thanks to 1) huge amounts of radicals formed in the solution via Fenton's response, in addition to those produced at the anode surface and 2) the proximity of the electro-Fenton's formed radicals to the contaminants molecules, because they are produced in the bulk and not in the proximity of the electrode surface [1] [10].

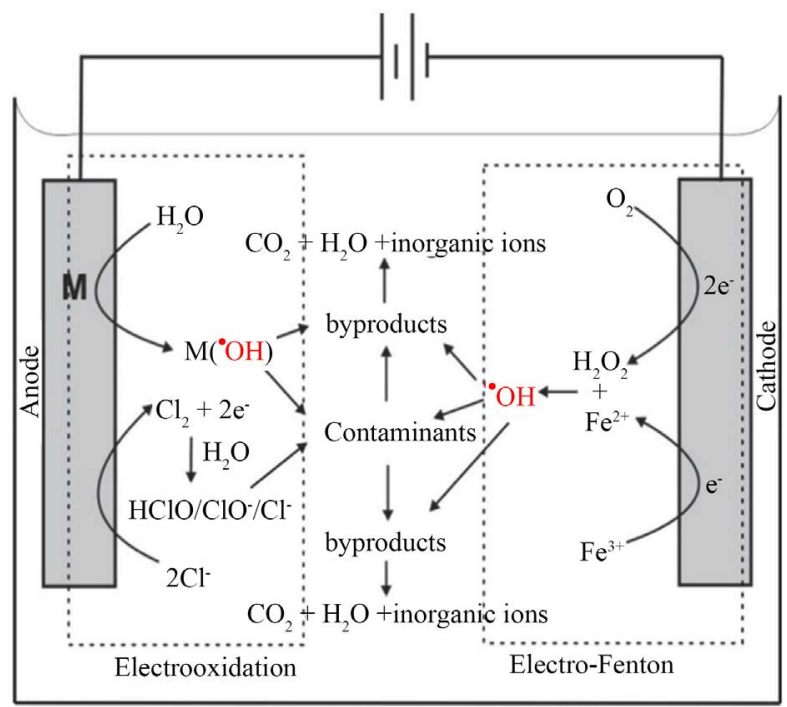

Figure 1. Schematic representation of pathway of oxidants formation in $\mathrm{EO}$ and electro-Fenton methods [1]. 


$$
\mathrm{H}_{2} \mathrm{O}_{2}+\mathrm{Fe}^{2+}+\mathrm{H}^{+} \rightarrow{ }^{\bullet} \mathrm{OH}+\mathrm{Fe}^{3+}+\mathrm{H}_{2} \mathrm{O}
$$

Photoelectro-Fenton technology is an amended version of electro-Fenton process, in which the solution remedied below electro-Fenton circumstances is at the same moment irradiated with UV light or solar irradiation (solar photoelectro-Fenton) to speed the mineralization rate of organic chemicals through the photolysis of $[\mathrm{Fe}(\mathrm{OH})]^{2+}$ (Equation (7)), therefore regenerating the $\mathrm{Fe}^{2+}$, that could catalyze the Fenton's response (Equation (6)) and form further ${ }^{\bullet} \mathrm{OH}[1]$. Furthermore, the irradiation of the purified solution caused the photolysis of the complexes of $\mathrm{Fe}$ (III) with formed carboxylic acids following Equation (8), so improving the performance of the solar photoelectro-Fenton [1].

$$
\begin{gathered}
{[\mathrm{Fe}(\mathrm{OH})]^{2+}+h v \rightarrow \mathrm{Fe}^{2+}+{ }^{\bullet} \mathrm{OH}} \\
{[\mathrm{Fe}(\mathrm{OOCR})]^{2+}+h v \rightarrow \mathrm{Fe}^{2+}+\mathrm{CO}_{2}+\mathrm{R}^{\bullet}}
\end{gathered}
$$

Such EAOPs are not the singular help of electrochemical engineering to keeping nature [21] [22] [23] [24]. Consequently, there are numerous different techniques prepared to deal with diverse ecological dares and which have been broadly investigated in last decades [25] [26] [27]. Concerning the treatment of liquid wastes, it is worth to mention three of them: electrocoagulation (EC) [28] [29] [30] [31] [32], electrodialysis, and capacitive deionization [1].

EC stays a standby to the chemical coagulation [33]-[41] as it employs electric current to generate coagulant species from the disintegration of sacrificial anodes (usually Fe or Al), being one of its major benefits since it averts chemical introduction and thus diminish process price [42] [43] [44]. Succeeding complex speciation procedures, which are a function of the $\mathrm{pH}$ and constitution of the waste, several coagulant species are produced in the reaction media, comprising not only the amorphous metal hydroxides but also numerous charged species [1] [45] [46]. Such species may neutralize the charges of micellar pollutants, supporting the generation of flocs from the colloidal particles carried in wastes with turbidity [47]; therefore, letting to separate contaminants from the wastewater [1] [48] [49]. The coalescence of coagulated solids is promoted via the soft mixing induced by the bubbles of hydrogen formed at the cathode [50] [51]. Such a technique is famous as electro-flocculation, being one of the fundamental merits of the whole EC method as it assists to keep mixing energy compared to traditional coagulation [52] [53]. Thus, such small bubbles could as well attach to the surface of the flocs, reducing their relative density, and letting their transport to the surface of the treated waste, where they could be readily eliminated [54]. Such procedure is familiar as electro-flotation [51] [55] and it is the major, but not the singular separation manner implied in the EC, since heavier coagulated solids are removed via deposition (Figure 2) [1] [56] [57]. The easier adjustment of $\mathrm{pH}$, the lower formation of sludge, and the lower effect on the conductivity remain the principal merits of the EC, which is as well beginning to be a technology with large pertinence in treating potable water [1] [58] [59]. 


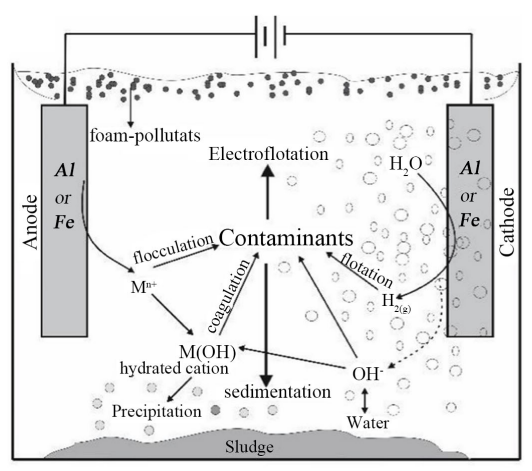

(a)

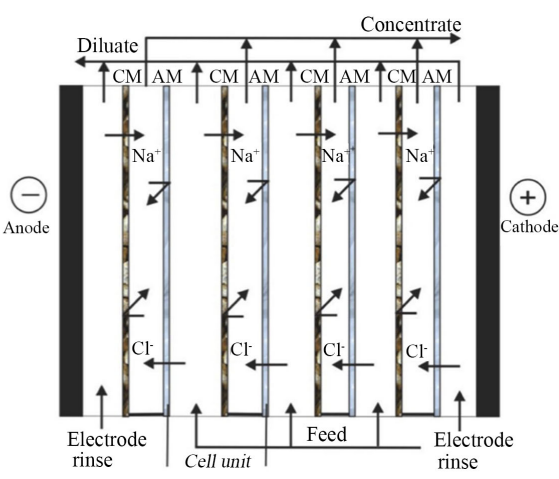

(b)

Figure 2. Schematic illustration of mechanisms of (a) electrocoagulation (EC) and (b) electrodialysis [1].

\section{Demobilizing Marine Heterotrophic Bacteria in Ballast Water via an EAOP}

Purifying seawater remains more and more requested because of manufacturing activities that employ huge quantities of seawater in their operations. The shipping industry and the related handling of a ship's ballast water are presently viewed as a worldwide dare for the seas. In this context, Moreno-Andrés et al. [60] estimated the aptness of an EAOP with BDD electrodes on a lab-scale for disinfecting seawater. Such a method could generate both ROSs and RCSs (predominately in seawater) that are in charge of killing pathogens. They utilized the EAOP in a continuous-flow regime with real seawater. They employed natural marine heterotrophic bacteria (MHB) as an index of disinfecting performance. A biphasic demobilization kinetic model was adapted on empirical points, attaining 4-Log removals at $0.019 \mathrm{Ah} / \mathrm{L}$. Through evaluating regrowth following remediation, their findings propose that higher bacterial harms follow from the EAOP when it is juxtaposed to chlorination. In addition, many problems needing basic comprehension were examined like recolonization potential or bacterial community dynamics. They deduced that even with disinfection techniques being efficacious, there is not only a possibility for regrowth following treatment but as well a modification on bacterial population diversity formed via the remediation. Energy consumption was evaluated and illustrated that 0.264 $\mathrm{kWh} / \mathrm{m}^{3}$ are required for 4.8-Log reductions of MHB; further, with 0.035 $\mathrm{kWh} / \mathrm{m}^{3}$, less disinfection performance could be reached (2.2-Log red). Nevertheless, with a remaining oxidant in the solution, full demobilization could be obtained during three days.

\section{Killing Staphylococcus aureus via EAOPs}

Valero et al. [61] worked on the Staphylococcus aureus demobilization in a simulated wastewater treatment plant effluent employing diverse electrochemical technologies, comprising the photo-electro-Fenton method. They controlled $S$. aureus, dissolved organic carbon (DOC), total oxidants and $\mathrm{H}_{2} \mathrm{O}_{2}$ levels, and $\mathrm{pH}$. 
They employed an electrolytic cell, involving a UVA lamp, a gas diffusion electrode (GDE) as a cathode and an $\mathrm{IrO}_{2}$ anode, to perform the trials below galvanostatic conditions $(20 \mathrm{~mA})$. Minimum demobilization (-0.4) and small DOC removal were obtained during 120 min when utilizing the $\mathrm{GDE}-\mathrm{IrO}_{2}$ setup, in which killing microbes was triggered via the produced $\mathrm{H}_{2} \mathrm{O}_{2}$. If the light was merged with GDE-IrO ${ }_{2}$, the technique performance observably augmented $(-3.7$ log demobilization) thanks to the interactive impact among UVA and $\mathrm{H}_{2} \mathrm{O}_{2}$. Injecting iron ( $\left.5 \mathrm{mg} \mathrm{L} / \mathrm{Fe}^{2+}\right)$ into the device also made bigger disinfection and DOC mineralization. The electro-Fenton method $\left(\mathrm{GDE}-\mathrm{IrO}_{2}+\mathrm{Fe}^{2+}\right)$ conducted to a bacterial removal of $-0.9 \mathrm{log}$ units and DOC decrease of $14 \%$; however, with the photo-electro-Fenton technique $\left(\mathrm{GDE}-\mathrm{IrO}_{2}+\mathrm{UVA}+\mathrm{Fe}^{2+}\right)-5.2$ units of microbes and $26 \%$ of DOC were reduced. Elevating the current intensity $(20 \mathrm{~mA}, 30$ $\mathrm{mA}$ and $40 \mathrm{~mA}$ ) in the photo-electro-Fenton device augmented $\mathrm{H}_{2} \mathrm{O}_{2}$ formation and, so, increased the bacterial demobilization $(-5.2 \log ,-6.2 \log$ and $-6.5 \log$, respectively). Nevertheless, the mineralization magnitude moderately augmented or rested almost the same. If juxtaposing the impact of $\mathrm{Fe}^{2+}$ and $\mathrm{Fe}^{3+}$ on photo-electro-Fenton, identical $S$. aureus demobilization was detected, whilst DOC reduction was bigger with $\mathrm{Fe}^{2+}$ (31\%) than with $\mathrm{Fe}^{3+}$ (19\%). Via trying the setup with a Ti anode, the straight anodic oxidation role of the $\mathrm{IrO}_{2}$ anode was categorized as minor.

\section{Electrodisinfecting Groundwater via an Effective Endogenous AOP}

De Battisti et al. [62] performed lab-scale tests employing real groundwater utilizing the $\mathrm{CabECO}^{\infty}$ reactor system with a view to estimating its aptness for treating water. They realized experiments in discontinuous and in continuous mode, exploring the effect of electrical and hydraulic process variables on the quality of treated water. Employing highly BDD electrodes in the device lets the electrosynthesis of important quantities of ozone. Due to the comparatively elevated quantity of chloride in the groundwater samples, a mixture of $\mathrm{HOCl} / \mathrm{OCl}^{-}$ was also synthesized. Rather by chance, elevating the current density in the examined span $100-1000 \mathrm{~A} / \mathrm{m}^{2}$ was joined by an augmentation in the faradaic yield of the electrosynthesis of oxidants, which was more noticeable for ozone than for free chlorine. As noted in the specialized publications, the major radical intermediate in the related reactions is ${ }^{\circ} \mathrm{OH}$, which could conduct to numerous oxidation products, that is ozone and $\mathrm{HOCl} / \mathrm{OCl}^{-}$. Treating electrolytically as well induced a reduction of the level of minor components, comprising $\mathrm{NH}_{4}^{+}$ and $\mathrm{Br}^{-}$. Additional by-products were $\mathrm{ClO}_{3}^{-}$and $\mathrm{ClO}_{4}^{-}$, even if their concentration levels were small. In addition, because of alkali generation at the cathode surface, the precipitation of calcium and magnesium carbonates was also noted. Moreover, the empirical examination depicted that even $P$. aeruginosa and Legionella could be fully eliminated in the treated stream, thanks to the singular ability of the device to form biocidal agents such as ozone, $\mathrm{HOCl} / \mathrm{OCl}^{-}$, and chloramines. Such impacts were especially obvious throughout batch trials [63]. 


\section{Conclusions}

From this work, the following conclusions can be drawn:

1) Moreno-Andrés et al. [60] followed the convenience of an EAOP using BDD electrodes for disinfecting seawater at a lab-scale. Through estimating demobilization kinetics, a biphasic deactivation strategy shows an excellent fit for MHB via acquiring disinfection variables like the electrical charge used that is required for attaining a 4-Log reduction $(0.019 \mathrm{Ah} / \mathrm{L})$ or a 3-Log reduction (0.007 Ah/L). Via juxtaposition with chlorination, it could be decided that employing BDD anodes engenders bigger cell demolition when an AEOP is implemented. These cell harms are adequate for stopping bacterial regrowth when total residual oxidants are maintained in a solution. Though disinfection methods could be efficacious, there is not only a possibility for regrowth following remediation but as well a bacterial succession phenomenon in which numerous bacterial groups may be controlling. Such detail possesses straight involvements on ballast water handling. Relying on the ecosystem condition of receiving waters, it could improve the potential introduction of aquatic invasive microorganisms that may conduct to grave ecological, economic, and health sequels.

2) Valero et al. [61] performed the photo-electro-Fenton with an in situ formation of $\mathrm{H}_{2} \mathrm{O}_{2}$ via a GDE, iron salts introduction and UVA light can completely demobilize $(-6 \log ) S$. aureus existing in synthetic wastewater effluent. Taking into account that, following $120 \mathrm{~min}$, only -0.5 log demobilization was obtained with UVA light alone and $-0.9 \log$ inactivation during the electro-Fenton process, it can be concluded that there is an interactive influence among light and the Fenton reagents that perceptibly augmented the formation of ROS. Real wastewater effluents may previously carry iron that could be sufficient to realize the Fenton response without the external introduction of iron salts. Natural solar light could be as well utilized, therefore diminishing energy consumption costs.

3) Electrochemically-driven techniques are earning importance thanks to encouraging findings noted in the literature. A shortage of comprehension in the pathways of electrode scaling and fouling has happened partially, because the most investigation is realized in batch reactors rather than continuous flow reactors where solutes and pathogens that noxiously influence setup efficiency pass by electrode surfaces. The coming study must confront the elephant in the room, the treatment of more realistic water matrices (i.e., composition and concentration). This will help to identify fit-for-purpose and niche opportunities for electrochemically-driven technologies [8].

\section{Acknowledgements}

This research has been funded by the Research Deanship of University of Ha'il, Saudi Arabia, through the Project RG-191190.

\section{Conflicts of Interest}

The authors declare no conflicts of interest regarding the publication of this paper. 


\section{References}

[1] Ganiyu, S.O., Martínez-Huitle, C.A. and Rodrigo, M.A. (2020) Renewable Energies Driven Electrochemical Wastewater/Soil Decontamination Technologies: A Critical Review of Fundamental Concepts and Applications. Applied Catalysis B: Environmental, 270, Article ID: 118857. https://doi.org/10.1016/j.apcatb.2020.118857

[2] Ghernaout, D. (2013) Advanced Oxidation Phenomena in Electrocoagulation Process: A Myth or a Reality? Desalination and Water Treatment, 51, 7536-7554. https://doi.org/10.1080/19443994.2013.792520

[3] Ghernaout, D. (2019) Brine Recycling: Towards Membrane Processes as the Best Available Technology. Applied Engineering, 3, 71-84.

[4] Moreira, F.C., Boaventura, R.A.R., Brillas, E. and Vilar, V.J.P. (2017) Electrochemical Advanced Oxidation Processes: A Review on Their Application to Synthetic and Real Wastewaters. Applied Catalysis B: Environmental, 202, 217-261.

https://doi.org/10.1016/j.apcatb.2016.08.037

[5] Ghernaout, D. (2019) Virus Removal by Electrocoagulation and Electrooxidation: New Findings and Future Trends. Journal of Environmental Science and Allied Research, 85-90. https://doi.org/10.29199/2637-7063/ESAR-202024

[6] Ghernaout, D. (2019) Electrocoagulation and Electrooxidation for Disinfecting Water: New Breakthroughs and Implied Mechanisms. Applied Engineering, 3, 125-133.

[7] Ghernaout, D. (2019) Reviviscence of Biological Wastewater Treatment: A Review. Applied Engineering, 3, 46-55.

[8] Garcia-Segura, S., Nienhauser, A.B., Fajardo, A.S., Bansal, R., Coonrod, C.L., Fortner, J.D., Marcos-Hernández, M., Rogers, T., Villagran, D., Wong, M.S. and Westerhoff, P. (2020) Disparities between Experimental and Environmental Conditions: Research Steps towards Making Electrochemical Water Treatment a Reality. Current Opinion in Electrochemistry. https://doi.org/10.1016/j.coelec.2020.03.001

[9] Ghernaout, D. and Elboughdiri, N. (2020) Advanced Oxidation Processes for Wastewater Treatment: Facts and Future Trends. Open Access Library Journal, 7, e6139. https://doi.org/10.4236/oalib.1106139

[10] Ghernaout, D., Elboughdiri, N. and Ghareba, S. (2020) Fenton Technology for Wastewater Treatment: Dares and Trends. Open Access Library Journal, 7, e6045. https://doi.org/10.4236/oalib.1106045

[11] Ghernaout, D. (2019) Disinfection via Electrocoagulation Process: Implied Mechanisms and Future Tendencies. EC Microbiology, 15, 79-90.

[12] Ghernaout, D. and Elboughdiri, N. (2019) Iron Electrocoagulation Process for Disinfecting Water: A Review. Applied Engineering, 3, 154-158.

[13] Ghernaout, D. and Elboughdiri, N. (2019) Electrocoagulation Process Intensification for Disinfecting Water: A Review. Applied Engineering, 3, 140-147.

[14] Ghernaout, D. and Elboughdiri, N. (2020) Electrochemical Technology for Wastewater Treatment: Dares and Trends. Open Access Library Journal, 7, e6020.

[15] Ghernaout, D., Alghamdi, A., Touahmia, M., Aichouni, M. and Ait Messaoudene, N. (2018) Nanotechnology Phenomena in the Light of the Solar Energy. Journal of Energy, Environmental \& Chemical Engineering, 3, 1-8. https://doi.org/10.11648/j.jeece.20180301.11

[16] Al Arni, S., Amous, J. and Ghernaout, D. (2019) On the Perspective of Applying of a New Method for Wastewater Treatment Technology: Modification of the Third Traditional Stage with Two Units, One by Cultivating Microalgae and Another by 
Solar Vaporization. International Journal of Environmental Sciences \& Natural Resources, 16, Article ID: 555934. https://doi.org/10.19080/IJESNR.2019.16.555934

[17] Ghernaout, D., Naceur, M.W. and Aouabed, A. (2011) On the Dependence of Chlorine By-Products Generated Species Formation of the Electrode Material and Applied Charge during Electrochemical Water Treatment. Desalination, 270, 9-22. https://doi.org/10.1016/j.desal.2011.01.010

[18] Boucherit, A., Moulay, S., Ghernaout, D., Al-Ghonamy, A.I., Ghernaout, B., Naceur, M.W., Ait Messaoudene, N., Aichouni, M., Mahjoubi, A.A. and Elboughdiri, N.A. (2015) New Trends in Disinfection By-Products Formation upon Water Treatment. Journal of Research \& Developments in Chemistry, 2015, Article ID: 628833. https://doi.org/10.5171/2015.628833

[19] Ghernaout, D. and Elboughdiri, N. (2020) Strategies for Reducing Disinfection By-Products Formation during Electrocoagulation. Open Access Library Journal, 7, e6076. https://doi.org/10.4236/oalib.1106076

[20] Ghernaout, D., Ghernaout, B. and Naceur, M.W. (2011) Embodying the Chemical Water Treatment in the Green Chemistry: A Review. Desalination, 271, 1-10. https://doi.org/10.1016/j.desal.2011.01.032

[21] Ghernaout, D. (2017) Microorganisms' Electrochemical Disinfection Phenomena. EC Microbiology, 9, 160-169.

[22] Irki, S., Ghernaout, D., Naceur, M.W., Alghamdi, A. and Aichouni, M. (2018) Decolorization of Methyl Orange (MO) by Electrocoagulation (EC) Using Iron Electrodes under a Magnetic Field (MF). II. Effect of Connection Mode. World Journal of Applied Chemistry, 3, 56-64. https://doi.org/10.11648/j.wjac.20180302.13

[23] Irki, S., Ghernaout, D., Naceur, M.W., Alghamdi, A. and Aichouni, M. (2018) Decolorizing Methyl Orange by Fe-Electrocoagulation Process: A Mechanistic Insight. International Journal of Environmental Chemistry, 2, 18-28. https://doi.org/10.11648/j.ijec.20180201.14

[24] Ghernaout, D., Touahmia, M. and Aichouni, M. (2019) Disinfecting Water: Electrocoagulation as an Efficient Process. Applied Engineering, 3, 1-12.

[25] Ghernaout, D., Alghamdi, A. and Ghernaout, B. (2019) Microorganisms' Killing: Chemical Disinfection vs. Electrodisinfection. Applied Engineering, 3, 13-19.

[26] Ghernaout, D. and Ghernaout, B. (2010) From Chemical Disinfection to Electrodisinfection: The Obligatory Itinerary? Desalination and Water Treatment, 16, 156-175. https://doi.org/10.5004/dwt.2010.1085

[27] Ghernaout, D. and Elboughdiri, N. (2020) UV $-\mathrm{C} / \mathrm{H}_{2} \mathrm{O}_{2}$ and Sunlight $/ \mathrm{H}_{2} \mathrm{O}_{2}$ in the Core of the Best Available Technologies for Dealing with Present Dares in Domestic Wastewater Reuse. Open Access Library Journal, 7, e6161. https://doi.org/10.4236/oalib.1106161

[28] Ghernaout, D., Al-Ghonamy, A.I., Naceur, M.W., Ait Messaoudene, N. and Aichouni, M. (2014) Influence of Operating Parameters on Electrocoagulation of C.I. Disperse Yellow 3. Journal of Electrochemical Science and Engineering, 4, 271-283. https://doi.org/10.5599/jese.2014.0065

[29] Ghernaout, D., Al-Ghonamy, A.I., Irki, S., Grini, A., Naceur, M.W., Ait Messaoudene, N. and Aichouni, M. (2014) Decolourization of Bromophenol Blue by Electrocoagulation Process. Trends in Chemical Engineering, 15, 29-39.

[30] Ghernaout, D., Al-Ghonamy, A.I., Ait Messaoudene, N., Aichouni, M., Naceur, M.W., Benchelighem, F.Z. and Boucherit, A. (2015) Electrocoagulation of Direct Brown 2 (DB) and BF Cibacete Blue (CB) Using Aluminum Electrodes. Separation Science and Technology, 50, 1413-1420. 
https://doi.org/10.1080/01496395.2014.982763

[31] Irki, S., Ghernaout, D. and Naceur, M.W. (2017) Decolourization of Methyl Orange (MO) by Electrocoagulation (EC) Using Iron Electrodes under a Magnetic Field (MF). Desalination and Water Treatment, 79, 368-377. https://doi.org/10.5004/dwt.2017.20797

[32] Ghernaout, D. (2018) Electrocoagulation Process: Achievements and Green Perspectives. Colloid and Surface Science, 3, 1-5. https://doi.org/10.11648/j.css.20180301.11

[33] Ghernaout, D. (2014) The Hydrophilic/Hydrophobic Ratio vs. Dissolved Organics Removal by Coagulation: A Review. Journal of King Saud University-Science, 26, 169-180. https://doi.org/10.1016/j.jksus.2013.09.005

[34] Ghernaout, D., Moulay, S., Ait Messaoudene, N., Aichouni, M., Naceur, M.W. and Boucherit, A. (2014) Coagulation and Chlorination of NOM and Algae in Water Treatment: A Review. International Journal of Environmental Monitoring and Analysis, 2, 23-34. https://doi.org/10.11648/j.ijema.s.2014020601.14

[35] Ghernaout, D., Al-Ghonamy, A.I., Boucherit, A., Ghernaout, B., Naceur, M.W., Ait Messaoudene, N., Aichouni, M., Mahjoubi, A.A. and Elboughdiri, N.A. (2015) Brownian Motion and Coagulation Process. American Journal of Environmental Protection, 4, 1-15. https://doi.org/10.11648/j.ajeps.s.2015040501.11

[36] Ghernaout, D., Al-Ghonamy, A.I., Naceur, M.W., Boucherit, A., Messaoudene, N.A., Aichouni, M., Mahjoubi, A.A. and Elboughdiri, N.A. (2015) Controlling Coagulation Process: From Zeta Potential to Streaming Potential. American Journal of Environmental Protection, 4, 16-27. https://doi.org/10.11648/j.ajeps.s.2015040501.12

[37] Ghernaout, D., Badis, A., Braikia, G., Matâam, N., Fekhar, M., Ghernaout, B. and Boucherit, A. (2017) Enhanced Coagulation for Algae Removal in a Typical Algeria Water Treatment Plant. Environmental Engineering and Management Journal, 16, 2303-2315. https://doi.org/10.30638/eemj.2017.238

[38] Ghernaout, D. (2017) Entropy in the Brownian Motion (BM) and Coagulation Background. Colloid and Surface Science, 2, 143-161.

[39] Ghernaout, D., Simoussa, A., Alghamdi, A., Ghernaout, B., Elboughdiri, N., Mahjoubi, A., Aichouni, M. and El-Wakil, A.E.A. (2018) Combining Lime Softening with Alum Coagulation for Hard Ghrib Dam Water Conventional Treatment. International Journal of Advanced and Applied Sciences, 5, 61-70. https://doi.org/10.21833/ijaas.2018.05.008

[40] Djezzar, S., Ghernaout, D., Cherifi, H., Alghamdi, A., Ghernaout, B. and Aichouni, M. (2018) Conventional, Enhanced, and Alkaline Coagulation for Hard Ghrib Dam (Algeria) Water. World Journal of Applied Chemistry, 3, 41-55. https://doi.org/10.11648/j.wjac.20180302.12

[41] Kellali, Y. and Ghernaout, D. (2019) Physicochemical and Algal Study of Three Dams (Algeria) and Removal of Microalgae by Enhanced Coagulation. Applied Engineering, 3, 56-64.

[42] Ghernaout, D., Aichouni, M. and Touahmia, M. (2019) Mechanistic Insight into Disinfection by Electrocoagulation: A Review. Desalination and Water Treatment, 141, 68-81. https://doi.org/10.5004/dwt.2019.23457

[43] Ghernaout, D., Alghamdi, A. and Ghernaout, B. (2019) Electrocoagulation Process: A Mechanistic Review at the Dawn of Its Modeling. Journal of Environmental Science and Allied Research, 2, 51-67. https://doi.org/10.29199/2637-7063/ESAR-201019 
[44] Ghernaout, D. (2019) Greening Electrocoagulation Process for Disinfecting Water. Applied Engineering, 3, 27-31.

[45] Ghernaout, D. (2019) Electrocoagulation Process for Microalgal Biotechnology: A Review. Applied Engineering, 3, 85-94.

[46] Ghernaout, D., Ghernaout, B., Saiba, A., Boucherit, A. and Kellil, A. (2009) Removal of Humic Acids by Continuous Electromagnetic Treatment Followed by Electrocoagulation in Batch Using Aluminium Electrodes. Desalination, 239, 295-308.

https://doi.org/10.1016/j.desal.2008.04.001

[47] Ghernaout, D., Ghernaout, B. and Boucherit, A. (2008) Effect of pH on Electrocoagulation of Bentonite Suspensions in Batch Using Iron Electrodes. Journal of Dispersion Science and Technology, 29, 1272-1275. https://doi.org/10.1080/01932690701857483

[48] Ghernaout, D. and Elboughdiri, N. (2020) Electrocoagulation Process in the Context of Disinfection Mechanism. Open Access Library Journal, 7, e6083.

[49] Ghernaout, D., Ghernaout, B. and Kellil, A. (2009) Natural Organic Matter Removal and Enhanced Coagulation as a Link between Coagulation and Electrocoagulation. Desalination and Water Treatment, 2, 203-222. https://doi.org/10.5004/dwt.2009.116

[50] Ghernaout, D., Ghernaout, B., Boucherit, A., Naceur, M.W., Khelifa, A. and Kellil, A. (2009) Study on Mechanism of Electrocoagulation with Iron Electrodes in Idealised Conditions and Electrocoagulation of Humic Acids Solution in Batch Using Aluminium Electrodes. Desalination and Water Treatment, 8, 91-99. https://doi.org/10.5004/dwt.2009.668

[51] Ghernaout, D., Naceur, M.W. and Ghernaout, B. (2011) A Review of Electrocoagulation as a Promising Coagulation Process for Improved Organic and Inorganic Matters Removal by Electrophoresis and Electroflotation. Desalination and Water Treatment, 28, 287-320. https://doi.org/10.5004/dwt.2011.1493

[52] Saiba, A., Kourdali, S., Ghernaout, B. and Ghernaout, D. (2010) In Desalination, from 1987 to 2009, the Birth of a New Seawater Pretreatment Process: Electrocoagulation: An Overview. Desalination and Water Treatment, 16, 201-217. https://doi.org/10.5004/dwt.2010.1094

[53] Ghernaout, D. and Boucherit, A. (2015) Review of Coagulation's Rapid Mixing for NOM Removal. Journal of Research \& Developments in Chemistry, 2015, Article ID: 926518. https://doi.org/10.5171/2015.926518

[54] Ghernaout, D., Mariche, A., Ghernaout, B. and Kellil, A. (2010) Electromagnetic Treatment-Bi-Electrocoagulation of Humic Acid in Continuous Mode Using Response Surface Method for Its Optimization and Application on Two Surface Waters. Desalination and Water Treatment, 22, 311-329. https://doi.org/10.5004/dwt.2010.1120

[55] Ghernaout, D., Benblidia, C. and Khemici, F. (2015) Microalgae Removal from Ghrib Dam (Ain Defla, Algeria) Water by Electroflotation Using Stainless Steel Electrodes. Desalination and Water Treatment, 54, 3328-3337.

https://doi.org/10.1080/19443994.2014.907749

[56] Ghernaout, D., Badis, A., Ghernaout, B. and Kellil, A. (2008) Application of Electrocoagulation in Escherichia coli Culture and Two Surface Waters. Desalination, 219, 118-125. https://doi.org/10.1016/j.desal.2007.05.010

[57] Belhout, D., Ghernaout, D., Djezzar-Douakh, S. and Kellil, A. (2010) Electrocoagulation of a Raw Water of Ghrib Dam (Algeria) in Batch Using Iron Electrodes. Desalination and Water Treatment, 16, 1-9. https://doi.org/10.5004/dwt.2010.1081 
[58] Ghernaout, D. and Ghernaout, B. (2011) On the Controversial Effect of Sodium Sulphate as Supporting Electrolyte on Electrocoagulation Process: A Review. Desalination and Water Treatment, 27, 243-254. https://doi.org/10.5004/dwt.2011.1983

[59] Ghernaout, D., Irki, S. and Boucherit, A. (2014) Removal of $\mathrm{Cu}^{2+}$ and $\mathrm{Cd}^{2+}$, and Humic Acid and Phenol by Electrocoagulation Using Iron Electrodes. Desalination and Water Treatment, 52, 3256-3270. https://doi.org/10.1080/19443994.2013.852484

[60] Moreno-Andrés, J., Ambauen, N., Vadstein, O., Hallé, C., Acevedo-Merino, A., Nebot, E. and Meyn, T. (2018) Inactivation of Marine Heterotrophic Bacteria in Ballast Water by an Electrochemical Advanced Oxidation Process. Water Research, 140, 377-386. https://doi.org/10.1016/j.watres.2018.04.061

[61] Valero, P., Verbel, M., Silva-Agredo, J., Mosteo, R., Ormad, M.P. and Torres-Palma, R.A. (2017) Electrochemical Advanced Oxidation Processes for Staphylococcus aureus Disinfection in Municipal WWTP Effluents. Journal of Environmental Management, 198, 256-265. https://doi.org/10.1016/j.jenvman.2017.04.070

[62] De Battisti, A., Formaglio, P., Ferro, S., Al Aukidy, M. and Verlicchi, P. (2018) Electrochemical Disinfection of Groundwater for Civil Use: An Example of an Effective Endogenous Advanced Oxidation Process. Chemosphere, 207, 101-109. https://doi.org/10.1016/j.chemosphere.2018.05.062

[63] Ghernaout, D. and Elboughdiri, N. (2020) Disinfection By-Products: Presence and Elimination in Drinking Water. Open Access Library Journal, 7, e6140. https://doi.org/10.4236/oalib.1106140 